\title{
ENHANCING TEACHING AND LEARNING OF OPEN AND DISTANCE LEARNING (ODL) STUDENTS WITH DISABILITIES USING DIGITAL TECHNOLOGIES AT UNIVERSITY, ZAMBIA
}

\author{
Rose Chikopela1i, \\ Daniel Ndhlovu², \\ Joseph M. Mandyata ${ }^{2}$, \\ Daniel L. Mpolomoka ${ }^{3}$, \\ Kasonde-Ng'andu Sophie ${ }^{2}$ \\ 1Zambia Institute of Special Education, \\ Lusaka, Zambia \\ 2University of Zambia, \\ Department of Educational Psychology, \\ Sociology and Special Education \\ Lusaka, Zambia \\ ${ }^{3}$ Zambian Open University, \\ Research and Consultancy Unit, \\ Lusaka, Zambia
}

\begin{abstract}
:
Technology is highly valued in modern day teaching and learning especially when it comes to imparting knowledge to students with disabilities. This paper presents the findings of a study that sought to establish the emerging and digital technologies being used to enhance the teaching and learning of ODL students with disabilities at Nkhruma University. The study used a case study design. The population comprised all students with visual and hearing impairment under ODL and their lecturers. A total sample of fifty-five (55) participants was employed and snowball sampling technique was utilized. The instruments used for data collection were interview guides and observation schedules. Data was analyzed thematically. The findings revealed that emerging technologies such as the use of information and communication technology were used by both students with visual and hearing impairment to learn effectively and lecturers to teach effectively. It was also revealed that digital technologies such as computers, cell phones, and Ipads were used during the lectures for effective teaching, easy access to materials and information. It was further revealed that some students with disabilities and lecturers were not well oriented on the use of modern ICT tools. Based on the
\end{abstract}

'Correspondence: email $\underline{\text { rchikopela@yahoo.com }}$ 
findings of the study, it was recommended that the institution conducts technologybiased capacity building workshops for all ODL lecturers.

Keywords: digital technology, students with disabilities, learning, teaching, university

\section{Introduction}

This paper presents the findings of a study that sought to establish the emerging and digital technologies being used to enhance the teaching and learning of ODL students with disabilities at Nkhruma University. The study is anchored on the assumption that technology is highly valued in modern day teaching and learning especially when it comes to imparting knowledge to students with disabilities.

\section{Objectives}

1. To establish the emerging digital technologies being used during teaching and learning of ODL students with disabilities at the University.

2. To ascertain whether the digital technologies being used at the University enhance the teaching and learning of ODL students with disabilities.

\section{Literature review}

Technology is one of the areas needed in the education of Open and Distance Learning (ODL) students with disabilities. Information and communication technology (ICT) has the potential to enhance participation in educational activities for (ODL) students with disabilities. ICT has higher quality scientific knowledge and techniques with its present connotation suitable for enhancing the learning needs of students with disabilities. The rationale for the use of information and communication technology (ICT), thrives on the manipulation and communication of information through voice, sound, or images, on computers, computer-based assistive technology, special software, and communication aids, in universities by (ODL) students with disabilities is to prepare all students for participation in the information society (Hakkarainen et al., 2000; Lei \& Zhao, 2007; Lidström \& Hemmingsson, 2014). A study by Massy and Zemsky (1995) revealed that the use of emerging technology brought the change to printing technology from free handwriting, which lasted for a long period of time. It was further observed that the use of information technology-enhanced academic productivity.

It is interesting to learn that teaching using ICT shortens the duration of instruction, keeps interests alive, embodies abstract concepts, provides realistic experiences, and creates more learning desires for students with disabilities. What is more, is that computer training programs help in improving the attention span and learning performance of (ODL) students with disabilities. This therefore positively influences academic skills, language, mathematics, literacy, and competence in these 
students (Brodin \& Lindstrand 2004). Computer training programs for general problemsolving skills such as mathematics and literacy skills are also frequently implemented by teachers of students with disabilities. Incorporating ICTs, particularly computers, and the Internet into teaching and learning in education to increase the (ODL) students' "digital skills" has become an important issue in both economically developed and rapidly developing countries (Reed \& Lahm, 2004). Computers are being used in improving the academic skills of (ODL) students with disabilities in special education, supporting many areas of development such as hand-eye coordination, small muscle motor skills, imitation, and language development (Lerner et al., 1987; Baglama et al., 2018; Matimba et al., 2019).

Researchers have emphasised that ICT, as a computer-based assistive technology device (ATD), has the potential to enable (ODL) students with disabilities to participate more fully in everyday activities, by giving them access to the class curriculum (Hasselbring, Glaser, 2000; Brodin \& Lindstrand 2004; Desch, Gaebler-Spira, 2008; Matimba et al., 2019). Computer-assisted instruction is a teaching method that consists of an environment in which learning takes place in the computer environment and uses a computer as a tool in teaching a lesson. It has a combination of self-learning principles with computer technology, which strengthens the teaching process and student motivation, which the learners can take advantage of according to their own learning speed. Students who use instructional software are learning how to use computers at their own pace and ability.

The environment also enables individualization of education (Baglama et al., 2018; Aksal, 2011) World Health Organization (WHO) emphasizes the importance of ATD mentioning that ATDs is one strategy that can be used by children with disabilities to improve functioning and minimize the impact of environmental barriers to their participation in everyday life, such as school activities. In Gersten and Baker's (1998) study, the use of technology in training applications has been shown to increase the academic success of learners. Use of software for computer-aided training in special education provides the benefits of individualization and self-improvement, immediate feedback, consistent correction process, repetition without pressure, immediate support, step-by-step training, frequent response by students, motivation, development of motor skills and visual-motor coordination, reduction of difficulties, intensification, psychological satisfaction and active learning of ODL students.

Furthermore, the use of technology in special education makes it easier for teachers to do their job and for individuals who need special education to understand and use the developing technology and to keep up with the innovations, and to ensure that the courses show parallelism with technological developments (Baglama et al., 2018).

One of the innovations that technology has made in the forefront in recent years is Tablet computers. These are mobile communication technologies which include mobile phones, smartphones, and tablets, as well as the use of Personal Digital Assistant (PDA). A study by Taylor (2012) showed that the use of digital and emerging technology enriches and supports lectures, seminars, meetings, and face-to-face tutorials. Tablets were 
preferred as teaching tools in education because they can connect to wireless networks and other computers. Additionally, tablets provide rich education and training environment for (ODL) students and teachers, which helps students increase their interest and desire in the lesson and helps their learning (Aksal, 2011; Haksiz, 2014). These students and teachers should receive continuous support and training according to their competencies in using Tablet PC to overcome the difficulties of using technology and enhance the learning of students with disabilities. Teachers' views on the use of tablet computers indicate that tablet computers should be used when teaching target skills, teaching self-care skills, gaining independence skills, and applying for awards in visual applications (Savas, 2013).

Research done by Gui-Rosenblit (2009) on distance education in the digital age revealed that the use of digital technology improved both teaching and learning due to the easy retrieval of the available material resources in the cases where textbooks were not available or proved to be very expensive.

In the proposals related to educational tools, teachers emphasized the importance of visual education tools for the students with hearing impairment and the use of technological educational tools such as computer-internet, television, video cassettes, and computer floppy disks. (Baglama et al., 2018; Chikopela et al., 2017). In a similar study, Tassel-Baska et al. (1999) suggested that technology should be integrated into training programs.

At Kwame Nkrumah University Open distance learning started in 1997 with the offering of diploma courses. In 2009, the programme changed to the offering of first degree. In the past when the diploma was being offered the use of modern technology like computers and cellphones was not mostly used for academic purposes as compared to the time when first degree programme started to be offered to date. The emerging and digital technology has been now utilized by lecturers and learners during teaching and learning periods. This study, therefore, sought to establish how digital technology was being used to enhance the teaching and learning of ODL students with disabilities at Nkrumah University.

\section{Methodology}

\subsection{Research design}

The study used case study design. Sturman (1997) defines a case study as a generic term for the investigation of an individual, group, or phenomena. A case study was used to gather information on digital technologies used to enhance the teaching and learning of ODL students with disabilities. The case study method seeks to describe a unit in detail, in context and holistically (Kombo and Tromp, 2006; Holstein \& Gubrium, 2011; Creswell, \& Plano Clark, 2011; Banda, et al., 2017). 


\subsection{Population and sample}

The population of this study comprised all students with disabilities under ODL and their lecturers. According to Kasonde-Ng'andu (2013), "A population is a group of individuals, objects or items from which samples are taken for measurement." A total sample of 30 participants was used (5 lecturers and 25 students).

\subsection{Sampling technique}

Purposive sampling technique was utilized in the study. Teachers and (ODL) students with disabilities were selected with a purpose in mind based on the skill and judgement on their experience in teaching and learning using digital technology. McMillan and Schumacher (2001:319) support the use of this technique. They contend that "the power and logic of purposive sampling is that a few cases studied in depth yield many insights about the topic, whereas the logic of probability sampling depends on selecting a random or statistically representative sample for generalisation to a larger population".

\subsection{Instruments and data analysis}

The interview guide and Focus Group Discussion guide were mainly used to collect data. The main task in interviewing the respondents was to understand the meanings of the interviewees or participants say about the topic under study and sought to cover both factual and meaningful levels of the themes under the study. The interview guide was used because it was particularly useful for getting the story behind a participant's experiences and the researcher pursued in-depth information around the topic. Thematic analysis was used to analyse data.

\section{Results and Discussion}

\subsection{Digital technologies being used by ODL lecturers and students}

It was reported that digital technology was used in the teaching and learning of students with disabilities at Kwame Nkrumah University under ODL. The digital technology that was indicated in Table 1 below.

Table 1: Forms of Technologies in use at the University

\begin{tabular}{|l|c|c|}
\hline Digital Technology & Score & $\mathbf{\%}$ \\
\hline Internet & 4 & 13 \\
\hline Social media & 5 & 17 \\
\hline Laptop & 3 & 10 \\
\hline Desktop computer & 5 & 17 \\
\hline Television & 5 & 17 \\
\hline Ipad & 1 & 3 \\
\hline Skype & 1 & 3 \\
\hline Cellphone & 4 & 13 \\
\hline Video chatting & 1 & 3 \\
\hline Youtube & 1 & 3 \\
\hline Total & 30 & 100 \\
\hline
\end{tabular}


Results show that social media, desktop computers, and television were the most used digital technology for teaching and learning of ODL students with disabilities. Lecturers mentioned that social media, through the use of WhatsApp groups for the class of students with disabilities made it easier for them to convey information faster. Whatsapp platform was used for class announcements, discussions, and sharing class notes. One lecturer said:

"The use of WhatsApp group has enabled me to communicate to all the students at once unlike calling them one by one when I have something to tell the class"

A student said:

"The technology that has come where we use Whats App group is very efficient. We receive class notes on the platform. We also hold group discussions when we are revising and preparing for exams. This is very beneficial especially to some of us who live very far away and cannot make it to discussions all the time."

Notwithstanding the above, technology has made communication easy between ODL students with disabilities and lecturers using WhatsApp group unlike some years back when lectures had to send modules by post. The use of postal services was not efficient because documents would not reach students on time and in some cases would go missing and students with disabilities would never receive them hence creating a communication breakdown between lecturers and students. Consistent with this finding, Massy and Zemsky (1995) established that the use of emerging information technology brought the change of printing technology from hand written and it lasted for a long period of time and enhanced academic productivity.

Desktop computers in the computer lab were used for teaching and learning ICT subjects. Teachers taught practical use of computers to students with disabilities. In addition, lecturers used computers to send assignments to students through emails. Students also mentioned that they used the university computers to type assignments and receive emails from their lecturers. Teachers said that use of computers when teaching was very effective in visual-spatial learning of students with hearing impairment. On the other hand, students with visual impairment benefited from using computers to write assignments, tests, and examinations. This finding corroborates with what Mpolomoka, et al. (2021) established regarding benefits learners with diverse needs derive from technology. For example, a student with visual impairment said that

"I write my assignments using the university computers in the computer lab instead of using braille".

Another student said: 
"I receive documents from my lecturers and send assignments to my lecturers using emails on the institution computers".

For this reason, the use of digital technology (like desktop computers) at the university has provided the most needed resource and acquisition of technological skills by students with disabilities. Similarly, Aksal (2011) and Mpolomoka et al. (2021) confirm that using the tools for technology in one environment also enables individualization of education for students. Students are able to work individually and consult where they are stuck.

The findings of this study showed that televisions were used to teach students with disabilities using DVDs that had lessons through watching some instructions on the lesson presented electronically. For example, one lecturer said:

"I teach Zambian sign language and some practical topics in some subjects using DVDs".

One student said:

"I watch DVDs and practice sign language. This makes me learn more because I rewind and watch it over and over again just to master some difficult signs"

In similar studies, Tassel-Baska et al. (1999) suggested that technology should be integrated into training programs; Chikopela, Sikanyika, Kalizinje, and Sondashi (2021); and Baglama et al. (2018) findings on teachers' proposals related to educational tools emphasized the importance of visual education tools for the students with hearing impairment and the use of technological educational tools such as computer-internet, television, video cassettes and computer floppy disks to learners with disabilities. This implies that using digital technology to deliver lessons to ODL students with disabilities has assisted students to watch and practice. This way their learning is enhanced.

The results of this study also showed that the use of laptops enhances the teaching and learning of ODL students with disabilities at Kwame Nkruma University. Some lecturers used projectors connected to the laptops to deliver lessons. Few students also used laptops to research and write their assignments. Students with disabilities confirmed that the use of projectors connected to laptops during lectures speeds up their learning. Due to this factor, demonstrations of some topics were also easy to follow and laptops are easy to carry. All the participants mentioned that laptops were very portable and useful for research. However, most students did not have laptops because they could not afford to buy them. One student said:

"I do not use a laptop to research because I cannot afford to buy it. I just rely on the computers in the computer lab when I am researching" 
This is in contrast with Gaebler-Spira, (2008) who emphasised that ICT, as a computer-based assistive technology device has the potential to enable students with disabilities to participate more fully in everyday activities, by giving them access to the class curriculum.

Another digital technology that was used is the internet. All the participants mentioned that they used the internet to research and get updated with information on their lessons. Lecturers explained that the internet was used to research and update their lessons. A lecturer said:

"We are living in the ICT era; it is now easy to gather data for lectures and modules from a lot of sources on the internet. The only challenge we have is internet connectivity. Sometimes the internet is not strong hence our pace to browse and download data becomes slow. This somehow contributes to our inability to prepare some information to use in the lessons and for our modules in good time."

Students also mentioned that the internet was used to research in order to come up with the contents of the assignments. One student said:

"I get a lot of information from the internet for my assignments within a short period of time when there is good internet connectivity."

This shows that the use of the internet promoted easy and quick access to information and promoted individual learning in ODL students with disabilities. Through research, a lot of knowledge has been acquired on a lot of issues that relate to the courses the students take especially when researching for assignment writing.

In support of this finding, Baglama et al., (2018) confirms that the use of technology in special education will make it easier for teachers to do their job and for individuals who need special education to understand and use the developing technology and to keep up with the innovations and technological developments. This study showed that the use of Ipads for teaching and learning was rare. Only one teacher had an Ipad that was used in teaching. The lecturer used the Ipad to present lectures. All the students did not have Ipads. Similarly, Savas's (2013) study on teachers' views on the use of tablet computers indicates that tablet computers should be used when teaching target skills, teaching self-care skills, gaining independence skills, and applying for awards in visual applications. This shows that most teachers and students do not make use of Ipads in their teaching and learning process. This limits the lecturers to teach ODL special education students target skills and self-care skills.

Skype was also another digital technology that was used by only one participant. A majority of the respondents had not used Skype in their lessons. The student who used Skype said: 
"I once used Skype to get clarity from one of the lecturers on how to go about my tutorial presentation"

A student who never used Skype said:

"I have never used Skype. I just make use of Whatsapp. For me, I think Whatsapp is more convenient than Skype."

The non-use of Skype could be due to the fact that most lecturers and students rely on WhatsApp for online face-to-face communication. This contrasts with what Taylor (2012) showed that the use of digital and emerging technology enriches and supports lectures, seminars, meetings, and face-to-face tutorials.

Cellphones were also discovered to enhance the teaching and learning of ODL students with disabilities. Whatsapp discussions were done through cellphones as well as most research. Both lecturers and students were able to download documents on their smartphones and used them for teaching and learning. One lecturer said:

"I mostly make use of my cellphone to download documents for lectures and then transfer them to my laptop because the internet is stable. The only challenge is that I have to buy the internet bundles with my own money even when the beneficiaries of the materials I download are the students who belong to this institution."

Additionally, participants mentioned that communication through cellphones was easier than any other form of communication because it provided immediate feedback. This implies that the use of this gadget promoted constant communication with students and lecturers. Similarly, a study by Gui-Rosenblit (2009) on distance education and the digital age revealed that the use of digital technology improved both teaching and learning due to the easy retrieval of the available material resources in cases where textbooks were not available or proved to be very expensive.

The findings of this study also showed that video chatting was another emerging technology that was used when learning. This compliments Chikopela, Sikanyika, Kalizinje, and Sondashi (2021) who confirm the same. Unanimously, students mentioned that video chats create face-to-face learning and enable students to participate in shared activities such as group presentations. The student said:

\section{"Sometimes I video chat with a friend when I need help on any class activity."}

For this reason, video chatting makes it easy for students with disabilities to share academic information whilst talking to each other. This also strengthens the socialization of these students because of their ability to see and read a person's emotions.

In addition, this study showed that youtube was another emerging technology that was used to learn some topics online. The majority of the students mentioned that 
youtube was useful in learning practical topics. They said that it was very easy to follow the instructions. This shows that youtube is another technology that is used by students with disabilities to learn. In support of this finding, Gersten and Baker's (1998) study, revealed that the use of technology in training applications has been shown to increase the academic success of learners.

\section{Conclusion and Recommendations}

The use of digital technology has enhanced the teaching and learning of ODL students with disabilities.

The study recommends that:

1. The institution conducts technology-biased capacity building workshops for all ODL lecturers.

2. The institution should sensitise lecturers and students with disabilities on the use of all digital technology to enhance teaching and learning.

3. The institution should have internet connectivity all the time.

\section{Conflict of Interest Statement}

The authors declare no conflicts of interest.

\section{About the Authors}

Rose Chikopela (PhD) is a Senior Lecturer at Zambia Institute of Special Education in the Department of Hearing Impairment. She has 13 years of professional experience in research and lecturing in the field of Special Education, Guidance, and Counselling. She has also published various articles in local and international refereed journals.

Daniel Ndhlovu (PhD) is a Senior Lecturer at the University of Zambia, member of the Special Education Association of Zambia, and a former President of the National Guidance and Counselling Association of Zambia (NAGCAZ). He holds a Doctor of Philosophy in Special Education, Master of Education in Special Education, and Bachelor of Education in Special Education from the University of Zambia. He also has a Diploma in Guidance, Counselling and Placement, Secondary School Teachers' Diploma, and Certificate in Accounts and Business Studies. To his credit, he has 37 years of teaching and administrative experience at the secondary and tertiary levels of education. He has served as Assistant Dean Postgraduate in the School of Education whose main responsibility was to coordinate postgraduate activities including their research. He has also served as Assistant Director responsible for postgraduate studies for the University of Zambia in collaboration with the Zimbabwe Open University at the Institute of Distance Education. He is a member of the University of Zambia Senate. He teaches Research Methods in Education, Guidance, and Counselling in Special Education. He has supervised more than 100 masters and $\mathrm{PhD}$ students who have graduated and have joined the labour market in employment. He has also been a consultant for local and 
international NGOs. He has also been a team leader on various assignments to write or develop teaching and learning materials for secondary and tertiary levels of education.

Joseph Mandyata (PhD) is currently a lecturer in special education, guidance, and counselling in the School of Education at the University of Zambia. He has served in various academic and education positions such as external and internal examiner of students at postgraduate level, Assistant Dean in the School of Education; Senior Inspector of Schools (special education); a District Inspector of Schools, Head teacher of special education school, special education teacher and as a Secondary School teacher in the Zambian Ministry of Education. He has researched and published several articles in the field of special and inclusive education and guidance and counselling in local and international journals. He holds a Doctor of Philosophy degree in Special education, Master of Education in Special Education) and a Bachelor of Arts with Education degree of the University of Zambia. He lectures in Special Education and guidance and counselling courses at both post and undergraduate degree programmes. His research interests are: Policies in Special / Inclusive Education; Partnerships in Special / Inclusive Education; Guidance and Counseling, Disability, Education and Poverty for persons with disabilities.

Daniel Lupiya Mpolomoka (PhD) is a Lecturer and Consultant at the Zambian Open University, Head of the Research and Consultancy Unit. He has 12 years of professional experience as a lecturer and researcher in the field of Literacy, Open and Distance Education in Higher Institutions of Learning, Adult Education, Special Education, and Education Studies. He has also published various articles in local and international refereed journals.

Sophie Kasonde-Ngandu (Prof.) is a senior lecturer in the Department of Educational Psychology, Sociology and Special Education in the School of Education at the University of Zambia. She teaches Educational Psychology and Educational Research.

\section{References}

Aksal, F.A. (2011). Developing evaluative tool for online learning and teaching process. TOJET: The Turkish Online Journal of Educational Technology, 10(3), 69-75.

Baglama, B., Haksiz, M. and Uzunboylu, H. (2018). Technologies Used in Education of Hearing Impaired Individuals. iJET - 13 (9). https://doi.org/10.3991/ijet.v13i09.8303

Banda, S., Mpolomoka, D.L., Mbono, D. and Sampa, R.L. (2017). "Use of questions in qualitative research: How questions guided our study", International Journal of Development Research, 7, (12).

Brodin J. and Lindstrand, P. (2004). Are computers the solution to support development in children in need of special support? Technol Disabil 16, 137-45.

Chikopela, R., Mpolomoka, D.L., Mandyata, J., Kaoma, S. and Ndhlovu, D. (2017). Attitude of teachers on pupils with hearing impairment in inclusive schools. Paper 
presented at the African Federation of Teaching Regulatory Authorities (AFTRA), 6th Teaching and Learning in Africa Conference and 8th Roundtable, University of South Africa, Pretoria, South Africa, 22-26 May, 2017.

Chikopela, R., Sikanyika, F.S., Kalizinje, C.N. and Sondashi, G. (2021). Digitalization of Teaching and Learning: Experiences and Opportunities in Selected Higher Learning Institutions in Zambia. International Journal of Research and Innovation in Social Science (IJRISS) V(IX), 43-53

Creswell, J. and Plano Clark, V. (2011). Designing and conducting mixed methods research (2 ${ }^{\text {nd }}$ ed.). Thousand Oaks, CA: Sage.

Desch L, Gaebler-Spira D. (2008). Prescribing Assistive-technology systems: Focus on children with impaired communication. J Pediatr 12, 1271-80.

Gersten, R. \& Baker, S. (1998). Real world use of scientific concepts: Integrating situated cognition with explicit instruction. Exceptional Children, 65(1), 23-25. https://doi.org/10.1177/001440299806500102

Guri-Rosenblit, S. (2009). Distance Education in digital age: Common misconceptions and the challenging tasks. Journal of distance education. 23(2), 105-122.

Hakkarainen, K., Ilomäki, L., Lipponen, L., Muukkonen, H., Rahikainen, M., Tuominen T., et al. (2000). Students' skills and practices of using ICT: Results of a national assessment in Finland. Comput Edu 34, 103-17.

Haksiz, M. (2014). Investigation of tablet computer use in special education teachers' courses. Procedia-Social and Behavioral Sciences, 141, 1392-1399. https://doi.org/10.1016/j.sbspro.2014.05.240

Hasselbring T. and Glaser, C. (2000). Use of computer technology to help students with special needs. Future child 10, 102-22.

Holstein, J. and Gubrium, J. (Eds.). (2011). Varieties of narrative analysis. Thousand Oaks, CA: Sage.

Kasonde-Ng'andu S. (2013). Writing a research proposal in educational research. Lusaka: UNZA Press.

Lei, J. and Zhao Y. (2007). Technology uses and student achievement: A longitudinal study. Comput Edu 49:284-96.

Lerner, J.W., Mardell-Czudnowski, C. and Goldenberg, D. (1987). Special education for the early childhood years. US: Prentice-Hall.

Lidström, H. and Hemmingsson, H. (2014). Benefits of the use of ICT in school activities by students with motor, speech, visual, and hearing impairment: A literature review. Scandinavian Journal of Occupational Therapy. February 2014 DOI: 10.3109/11038128.2014.880940.

William F. Massy and Robert Zemsky (1995). Using information technology to enhance academic productivity. Washington: Educom.

Matimba, M., Mpolomoka, D.L. and Muvombo, M. (2019). Access to Computer Assisted Learning (CAL) for Children with Disabilities in Schools in Lusaka District. Proceedings of the 16th Biennial conference of the International Association of Special Education held Magamba, Tanzania, July 14-17, 2019, themed: Empowering 
Persons with Disabilities: Developing Resilience and Inclusive Sustainable Development. An Independent Publication of the International Association of Special Education. (ISBN: 978-0-9890212-3-4) Pp. 125-127.

Mpolomoka, D.L., Chembe, C., Chikopela, R., Zulu, E. and Nachinanga, C. (2021). Teaching differently-abled learners Design and Technology: A Review. Paper presented at the $18^{\text {th }}$ Conference on Mathematics, Science and Technology Education in Africa [COMSTEDA 18], November 23 ${ }^{\text {rd }}-25^{\text {th }}, 2021$ University of Rovuma, Nampula-Mozambique.

Mukul, G. and Deepa, G. (2013). Research Methodology. Delhi: PHI Learning private limited.

Reed, P. and Lahm, E. (2004). Assessing students' needs for assistive technology: A resource manual for school district teams. US: Wisconsin Assistive Technology Initiative.

Savas, P. (2013). Tablet PCs in English Language Teaching: Benefits and challenges. Global Journal on Technology, 4, 602-607.

Tassel-Baska, J., Leonhard, P., Glenn, C., Poland, D., Brown, E. and Johnson, D. (1999). Curriculum review as a catalyst for gifted education reform at the secondary level. Journal of Secondary Gifted Education, 10(4), 473 - 481.

Taylor, F. (2012). Using technology for enhancing teaching and learning in Bangladeshi: Challenges and consequences. Learning media and technology. 37(4), 414-428. 
Rose Chikopela, Daniel Ndhlovu, Joseph M. Mandyata, Daniel L. Mpolomoka, Kasonde-Ng'andu Sophie ENHANCING TEACHING AND LEARNING OF OPEN AND DISTANCE LEARNING (ODL) STUDENTS WITH DISABILITIES USING DIGITAL TECHNOLOGIES AT UNIVERSITY, ZAMBIA

Creative Commons licensing terms

Authors will retain the copyright of their published articles agreeing that a Creative Commons Attribution 4.0 International License (CC BY 4.0) terms will be applied to their work. Under the terms of this license, no permission is required from the author(s) or publisher for members of the community to copy, distribute, transmit or adapt the article content, providing a proper, prominent and unambiguous attribution to the authors in a manner that makes clear that the materials are being reused under permission of a Creative Commons License. Views, opinions and conclusions expressed in this research article are views, opinions and conclusions of the author(s). Open Access Publishing Group and European Journal of Open Education and E-learning Studies shall not be responsible or answerable for any loss, damage or liability caused in relation to/arising out of conflict of interests, copyright violations and inappropriate or inaccurate use of any kind content related or integrated on the research work. All the published works are meeting the Open Access Publishing requirements and can be freely accessed, shared, modified, distributed and used in educational, commercial and non-commercial purposes under a Creative Commons Attribution 4.0 International License (CC BY 4.0). 